\title{
Real Exchange Rate Volatility, Economic Growth and the Euro
}

\author{
Thorsten Janus \\ University of Wyoming, Laramie, USA \\ Daniel Riera-Crichton \\ Bates College, Lewiston, USA
}

\begin{abstract}
This paper studies the impact of real effective exchange rate volatility on economic growth as well as the euro's impact on real effective exchange rate volatility. We first show that after a plausible endogeneity correction, real effective exchange rate volatility is negatively associated with growth in a 1980 2011 panel of the OECD (Organization for Economic Cooperation and Development) countries. A one standard deviation volatility decrease is associated with a two percentage points growth increase. Second, we find that the euro adoption was associated with a decline of 0.4 standard deviations in long-run real effective exchange rate volatility before the Great Recession in 2008 2009. Moreover, while the Great Recession increased real effective exchange rate volatility by $38 \sim 189 \%$ of the sample mean for the countries outside the eurozone, the real effective exchange rate of the euro adopters were almost completely insulated. We conclude that real effective exchange rate stability may be growth-enhancing in the OECD countries and that the euro have played a growth-enhancing role at least before the recent eurozone debt crisis.
\end{abstract}

\footnotetext{
* Corresponding Author: Thorsten Janus; University of Wyoming, Department of Economics \& Finance, Department. 3985, 1000 E. University Ave., Laramie, WY 82071, USA; Tel: +1 3077663384, Fax: +1 3077665090, E-mail: tjanus@ uwyo.edu.

Co-Author: Daniel Riera-Crichton; Bates College, Department of Economics, Pettengill Hall, Room 273, Lewiston, ME 04240, USA; Tel +1 2077866084, E-mail: drieracr@bates.edu.
} 
JEL Classification: F31, F32, F33

Keywords: Euro, Great Recession, Economic Integration, Real Exchange Rates

\section{Introduction}

This paper seeks to address the effect of Real Effective Exchange Rate (REER) volatility on economic growth. Although Eichengreen's (2007) survey concludes that REER stability is likely to be a facilitating condition for growth, it notes that the evidence should be interpreted with caution since few studies control for reverse causality and many rely on a cross-section of countries. Recently, Aghion et al. (2009) finds that REER volatility is negatively associated with labor productivity growth if financial development is below a certain threshold. Although their study has the advantage of using a panel rather than cross-section of countries, their identification strategy however, assumes that REER volatility and its interaction with financial development are uncorrelated with future realizations of the error term. In this paper, instead we study the effect of REER volatility on growth in a panel of Organization for Economic Cooperation and Development (OECD) countries where we instrument REER volatility with a commodity term of trade volatility measure. Though it is not entirely clear that REER volatility is the only mechanism linking terms of trade volatility to growth, ${ }^{1}$ it seems likely to explain most of the transmission. To follow up on the evidence, we further ask how the eurozone's common currency adoption has affected the member countries' REER volatility. ${ }^{2}$

Our principal findings can be summarized as follows. (i) REER volatility is negatively associated with growth in the OECD sample. A one standard deviation decrease in volatility is associated with a growth increase of approximately two percentage points (0.8 standard deviations). This estimate contrasts with Aghion et al. (2009), who finds a positive effect on labor productivity only in financially underdeveloped economies. (ii) Euro adoption was associated with a decline of about 0.4 standard deviations in long-run

\footnotetext{
${ }^{1}$ We thank Yao Tang for this observation.

${ }^{2}$ Papaioannou and Portes (2008) discuss the potential benefits and costs of the euro in detail. Apart from increasing REER stability, the euro may increase international trade, investment and liquidity, provide a new global reserve currency, and decrease and stabilize inflation.
} 
REER volatility before the onset of the Great Recession in 2008 2009. Moreover, while the Great Recession increased volatility by $38 \sim 189 \%$ of the sample mean $(0.4 \sim 2$ standard deviations) outside the eurozone, the REERs of euro adopters were almost completely insulated. On this basis, we conclude that the euro may have increased economic growth by stabilizing the real exchange rates of member countries over the sample years. That being said, we should emphasize that our sample ends in 2009, which is just before the recent debt crisis in the eurozone.

In the remainder of the paper, Section II describes our data. Section III studies the effect of REER volatility on economic growth. Section IV reviews the theoretical underpinnings linking euro adoption to REER stability as well as preliminary evidence linking the two empirically. Section V estimates the effect of euro adoption and Section VI concludes.

\section{Data}

We obtained real Gross Domestic Product (GDP) data of 2005 US dollars from the International Monetary Fund's International Financial Statistics (IFS). We use the deflator provided by the IMF to deflate the nominal value of domestic currency GDP and then transform that value into US dollars using the nominal exchange rate provided in the IFS. We also obtained some real GDP data from OECD Source, Economic Intelligence Unit (EIU), DataStream (DS), and CEIC Data Company Ltd. We then compute GDP per capita with population data from the Penn World Tables. We record total gross capital flows as the sum of the absolute value of all liability increases and decreases plus total asset increases and decreases in the capital and financial balances as reported in the IMF's Balance of Payments Statistics (BOPS). We additionally obtained current account data from BOPS and domestic Consumer Price Index (CPI) inflation from IFS, DS, EIU, and CEIC. To estimate the effect of REER volatility on growth, we use Commodity Terms-of-Trade (CTOT) data from Aizenman et al. (2012). The CTOT index is the ratio of a weighted average price of a country's main commodity exports to a weighted average price of its main commodity imports. Specifically, the CTOT for country $j$ in period $t$ is $C T O T_{j t}=\prod_{i}\left(P_{i t} / M U V_{t}\right)^{X_{j}^{i}} / \prod_{i}\left(P_{i t} / M U V_{t}\right)^{M_{j}^{i}}$, where $P_{i t}$ is a common price index for six commodity categories consisting of food, fuels, agricultural 
raw materials, metals, gold, and beverages in year $t ; X_{j}^{i}$ is country $j$ 's average share of exports of commodity $i$ as a percent of GDP from 1970 to 2009; $M_{j}^{i}$ is the corresponding average share of imports. The commodity prices are deflated by a Manufacturing Unit Value (MUV) index. Since $X_{j}^{i}$ and $M_{j}^{i}$ are averaged over time, the movements in $C T O T_{j t}$ are invariant to changes in export and import volumes in response to price fluctuations. They, therefore, isolate the impact of commodity prices on a country's commodity terms of trade. By excluding industrial goods, and concentrating on commodity prices, the CTOT focuses on a highly volatile component of import and export prices. We refer to Aizenman et al. (2012) for more details and data sources. To measure the Real Effective Exchange Rate (REER), we use an index which represents a trade-weighted nominal effective exchange rate index adjusted for relative movements in national prices, $R E E R=\Pi_{i}\left[\left(e / e_{i}\right)\left(P / P_{i}\right)\right]^{w_{i}}$, where $e$ is the nominal exchange rate of the subject currency against the US dollar (US dollars per currency in index form), $e_{i}$ is the exchange rate of the subject country's trade partner $i$ against the US dollar (US dollars per currency $i$ in index form), and $w_{i}$ is the bilateral trade based weight attached to trade partner $i$ in the index. The weights are calculated based on the sum of bilateral exports and imports. The variable $P$ is the CPI of subject country and $P_{i}$ is the CPI of its trade partner. An increase in the REER implies a real appreciation. The data is obtained from the IFS, OECD, and JP Morgan. In order to control for the Harrod-Balassa-Samuelson effect, i.e., the hypothesis that productivity tends to grow faster in the tradables than the nontradables sector and therefore GDP growth may be correlated with REER appreciation (Rogoff 1996), we compute relative non-tradables Total Factor Productivity (TFP) growth as the weighted average TFP growth in non-tradables industries relative to weighted average TFP growth in tradeables industries. The industry TFP growth data is from the OECD Source dataset, where we define agriculture, mining, manufacturing, and energy as tradable sectors, while construction, wholesale and retail trade, finance, and business sector services as non-tradables sectors. The weights used to aggregate the industries in a sector were calculated using industry value added from the UN data. Lastly, we obtain data for the stock of reserves as the total stock of international reserves minus gold based on the IFS, DS, and EIU, and we compute trade openness as the sum of merchandise exports and imports divided by twice the value of nominal GDP, all in the current US dollars. The data for imports and exports was extracted from the IFS, DS, EIU, and CEIC.

\footnotetext{
${ }^{3}$ We thank an anonymous referee for this suggestion.
} 


\section{Real Exchange Rate Volatility and Growth}

In this section, we estimate the effect of REER volatility on the economic growth in a panel of OECD countries. There are several reasons to expect a negative effect. As discussed in Calvo et al. (1996), a volatile REER may encourage foreign-financed spending booms when the exchange rate is high, followed by costly busts due to credit crunches and a rising real value of foreign-currency denominated debt when the exchange rate falls. Martin and Rogers (2000) argue that boom-bust cycles can prevent learning-by-doing and therefore reduce an economy's long-term growth rate. Following Dixit and Pindyck (1994), the uncertainty associated with volatility may induce firms to postpone irreversible investments. Cottani et al. (1990) notes that REER volatility may force investors to pay adjustment costs to move across countries or between tradable and non-tradable sectors. ${ }^{4}$

\section{A. Estimation strategy}

In order to identify the empirical growth effect of REER volatility, it is important to control for reverse causality, e.g., a growth decline might destabilize the REER as foreign capital flees the economy, as well as other sources of potential endogeneity. In order to address the endogeneity concern, we focus on the estimation of Instrumental Variables estimation (IV) of the growth rate of real GDP in an annual panel of OECD countries from 1980 to 2011 . We measure REER volatility as the standard deviation of the REER over the twelve months of each calendar year and instrument this measure with the standard deviation of the CTOT index over the same period. The empirical growth specification is

$$
g_{i t}=\alpha_{0}+\alpha_{1} \text { REERVol }_{i(t-1)}+\alpha_{2} \text { Crisis }+\alpha_{3} t+\alpha_{4} \vec{x}_{i(t-1)}+\phi_{i}+\varepsilon_{i t}
$$

where $g_{i t}$ is the growth rate (change in the natural logarithm) of real GDP in country

\footnotetext{
${ }^{4}$ As noted, the empirical literature remains unsettled. Cottani et al. (1990) find that real exchange rate stability is associated with increased investment and growth in developing countries. Dollar (1992) and Bosworth et al. (1995) link it to growth and Ghura and Grennes (1993) and Bleaney and Greenaway (2001) link it positively to investment but find no evidence of a growth effect for Sub-Saharan Africa. Most recently, Aghion et al. (2009) link REER stability to productivity growth in financially underdeveloped economies.
} 
$i$ in year $t, \ln Y_{i t}-\ln Y_{i(t-1)}$. On the right hand side, REERVol $l_{i(t-1)}$ is the lagged value of REER volatility, Crisis is a dummy for the Great Recession that is equal to one in 2008 and 2009, $t$ is a time trend, $\vec{x}_{i(t-1)}$ is a vector of other controls, $\phi_{i}$ is a country fixed effect, and $\varepsilon_{i t}$ is an i.i.d. error term. The lagged measure of real exchange rate volatility, $R_{E E R V_{i(t-1)}}$, is estimated in the first stage of the IV procedure using the lagged volatility of the country's commodity terms of trade, CTOTVol $l_{i(t-1)}$, as an instrument. Although in principle, IV estimation makes it unnecessary to include other growth determinants, we control for the lagged growth rate of TFP in the non-tradables sector relative to the tradables sector, the lagged value of GDP per capita and its square, trade openness, inflation, and squared inflation. The first control intends to capture the Harrod-Balassa-Samuelson effect explained in Section II. The other controls capture the stylized facts that middle income economies, more open economies, and economies with moderate inflation tend to grow faster. Income per capita, openness, and inflation could also be correlated with REER volatility if high-income countries have a larger non-tradables share in GDP, more open economies are more likely to sustain purchasing power parity due to the lack of trade barriers, or higher inflation destabilizes the nominal exchange rate. We refer to Dornbusch (1985), De Gregorio et al. (1994), and Rogoff (1996) for more detailed discussions. Tables 1 2 display the summary statistics and sample countries.

\section{B. Results}

The estimates in Table 3 are consistent with a negative effect of REER volatility on growth: one standard deviation decrease in REER volatility is associated with a $1.7 \sim 2.3 \%$ growth increase depending on the specification. ${ }^{5}$ The first stage estimates show that commodity terms of trade volatility is a good predictor of REER volatility: the Kleibergen-Paap Rk Wald F statistics consistently reject that the model is underidentified and that the true size of the 5\% significance test exceeds $10 \%$ due to weak instruments (Stock and Yogo 2002).

${ }^{5}$ Including all controls in the same regression yields a very similar estimate of -0.018 (significant at the $10 \%$ level). 


\section{The Euro and Real Effective Exchange Rate Stability}

Prior to estimating the euro's effect on REER stability, we briefly consider the theoretical underpinnings linking the two and some simple preliminary evidence. On the theoretical side, although it may seem obvious that a common currency implies a fixed exchange rate, this conclusion for the euro would be false for two reasons. First, the euro only fixes exchange rates within the eurozone. Second, if prices are flexible, the REER can fluctuate despite a common currency. In fact, Berka et al. (2012, P. 179) takes issue with the classical Freidman critique that fixed exchange rates are destabilizing and conclude that real exchange rates within the eurozone adhere fairly closely to the efficient outcome. Berka and Devereux (2013) similarly finds that real exchange rates within the eurozone have adjusted substantially towards purchasing power parity via inflation differentials.

In order to link the euro formally to REER volatility, we note that a euro country's REER can be written as

$$
\left.R E E R=\prod_{i=1}^{N}\left[e_{i} q_{i}\right)\right]^{w_{i}}=\prod_{i=1}^{M}\left[e_{i} q_{i}\right]^{w_{i}} \times \prod_{i=M+1}^{N}\left[e_{i} q_{i}\right]^{w_{i}}
$$

where countries 1 to $M$ are other euro countries, countries $M+1$ to $N$ are non-euro countries, $q_{i} \equiv P / P_{i}$ is the domestic currency price level relative to the foreign currency price level of trading partner $i, e_{i}$ is the nominal exchange rate with this trading partner, and $w_{i}$ are bilateral trade weights. ${ }^{6}$ In $\log s$,

$$
\ln (R E E R)=\sum_{i=1}^{M} w_{i} \ln e_{i} q_{i}+\sum_{i=M+1}^{N} w_{i} \ln e_{i} q_{i}
$$

From Equation (3), the variance of the log REER before the euro's introduction is

$$
\begin{aligned}
\sigma_{\ln (R E E R)}^{2}=\sum_{i=1}^{M} w_{i}^{2} \sigma_{\ln \left(e_{i} q_{i}\right)}^{2}+\sum_{i=M+1}^{N} w_{i}^{2} \sigma_{\ln \left(e_{i} q_{i}\right)}^{2} \\
\\
2 \operatorname{cov}\left(\sum_{i=1}^{M} w_{i} \ln \left(e_{i} q_{i}\right), \sum_{i=M+1}^{N} w_{i} \ln \left(e_{i} q_{i}\right)\right)
\end{aligned}
$$

\footnotetext{
${ }^{6}$ Due to data limitations, in the empirical section we compute bilateral nominal exchange rates as the ratio of the two countries' exchange rates relative to the US dollar.
} 
where the first term is the variance of the REER against future euro members, the second term is the variance against non-members, and the third term is the covariance of REERs viz- $a$-viz members and non-members. After the eurozone is formed, REER variance becomes

$$
\sigma_{\ln (R E E R)}^{2}=\sum_{i=1}^{M} w_{i}^{2} \sigma_{\ln \widetilde{q}_{i}}^{2}+\sum_{i=M+1}^{N} w_{i}^{2} \sigma_{\ln \left(\tilde{e}_{i} \widetilde{q}_{i i}\right)}^{2}+2 \operatorname{cov}\left(\sum_{i=1}^{M} w_{i} \ln \widetilde{q}_{i}, \sum_{i=M+1}^{N} w_{i} \ln \left(\widetilde{e}_{i} \widetilde{q}_{i}\right)\right)
$$

where relative price levels and nominal exchange rates with respect to all trading partners will change to some $\widetilde{q}_{i} \neq q_{i}$ and $\widetilde{e}_{i} \neq e_{i}$, with $\widetilde{e}_{i} \equiv 1$ for the $M$ euro partners. For example, Ireland's price level relative to both the US and Germany will change and its previous pound-dollar and pound-deutschmark exchange rates are now the euro-dollar exchange rate and unity, respectively. Subtracting Equation (4) from (5) gives change in REER variance due to the euro:

$$
\begin{aligned}
& \Delta \sigma_{\ln (\text { REER })}^{2}=\left(\sum_{i=1}^{M} w_{i}^{2} \sigma_{\ln \widetilde{q}_{i}}^{2}-\sum_{i=1}^{M} w_{i}^{2} \sigma_{\ln \left(e_{i} q_{i}\right)}^{2}\right)+\left(\sum_{i=M+1}^{N} w_{i}^{2} \sigma_{\ln \left(\tilde{e}_{i} \tilde{q}_{i}\right)}^{2}-\sum_{i=M+1}^{N} w_{i}^{2} \sigma_{\ln \left(e_{i} q_{i}\right)}^{2}\right) \\
& +2\left\{\operatorname{cov}\left(\sum_{i=1}^{M} w_{i} \ln \widetilde{q}_{i}, \sum_{i=M+1}^{N} w_{i} \ln \left(\widetilde{e}_{i} \widetilde{q}_{i}\right)\right)-\operatorname{cov}\left(\sum_{i=1}^{M} w_{i} \ln \left(e_{i} q_{i}\right), \sum_{i=M+1}^{N} w_{i} \ln \left(e_{i} q_{i}\right)\right)\right\}
\end{aligned}
$$

where the three terms are, respectively, the change in variance against members, the change in variance against non-members, and the change in the covariance term.

Equation (6) shows three effects of introducing the euro. The first term is the fall in REER variance relative to euro members due to fixing the nominal exchange rate completely. The second term is a rise in variance if the post-euro REER relative to nonmembers is more volatile than its pre-euro counterpart. For example, with the loss of autonomous monetary policy, Ireland can no longer stabilize its nominal exchange rate against its largest trading partner, the US. As a result, Ireland's real euro-dollar exchange rate might fluctuate more than its earlier real pound-dollar exchange rate. Its overall REER relative to non-euro members can therefore be more unstable, i.e., the second term in Equation (6) can be positive. The third term can similarly destabilize the REER if, again using the Ireland example, the covariance between the real pound-deutschmark and real pound-dollar exchange rates before the euro was smaller than the covariance between the relative Irish-German price level and the real Irish euro-dollar exchange rate. For example, if relative price levels are constant in the short run and the Irish pound used 
to fall against the dollar when it rose against the deutschmark, then the first covariance term in Equation (6) will be close to zero and the second term will tend to be negative. In this case, prior to the euro, Ireland could use the deutschmark to hedge against dollar fluctuations - net exports to Germany might boom when net exports to the US declined - but the euro prevented this hedging.

Despite the theoretically ambiguous effect of the euro, Figure 1 suggests that, in practice, the euro has stabilized the member REERs quite significantly. The two curves show the unweighted country average REER volatility for euro and non-euro adopters from before to after 1999 . While the two country groups show similar REER volatility prior to euro adoption, the euro members had much more stable REERs subsequently. The volatility differential grew sharply in the lead up to the Great Recession when, as Figure 2 shows, the real depreciations experienced by non-members were larger by an order of magnitude. When we formally decompose the REER variances of individual euro members and the overall eurozone using Equations (4) (6), we find the results shown in Table 4. The trade weights used for the decomposition are average 1970 2006 bilateral trade weights, which is summarized in Table 5. Table 6 shows that the eurozone's average decline in REER volatility after adoption was mostly (57\%) due to decreased volatility against other euro members. However, declining variance against non-members accounted for $17 \%$ and less covariance between the REER with members and the REER with non-members accounted for $25 \%$ of the total variance decline.

\section{Estimation of the Euro's Effect}

In this section, we formally estimate the euro's effect on REER volatility. Because we have sufficient data and the REER can show high-frequency movements, we estimate a quarterly rather than annual panel. The quarterly volatility of the REER is computed by first calculating the standard deviation between two months prior and two months after the current month. We then take the average variance across the three months of every quarter. Formally,

$$
\operatorname{REERVO}_{i t}=\frac{1}{3}\left(\sigma_{s-2, s+2}+\sigma_{s-1, s+3}+\sigma_{s, s+4}\right)
$$


where $t$ and $s$ count, respectively, the number of quarters and the number of months in the dataset.

\section{A. Estimation strategy}

REER volatility has a strong autoregressive component and Least Squares Dummy Variables (LSDV) estimates of dynamic panels suffer from bias due to endogeneity among the independent variables (Nickell 1981). We therefore estimate a random effects model following Hausman and Taylor (1981) and Amemiya and MaCurdy (1986). The resulting Hausman-Taylor estimators are frequently used in dynamic panel estimation and are derived in Greene (2002). Their key advantage is to allow some of the covariates, such as the lagged dependent variable, to be correlated with the unobserved individuallevel random effect. ${ }^{7}$ The estimating equation is the following:

$$
\begin{aligned}
& \text { REERVol }_{i t}=\delta_{0}+\delta_{1} \text { REERVol }_{i(t-1)}+\delta_{2} \text { Euro }_{i(t-1)}+\delta_{3} \text { Crisis }_{(t-1)} \\
& +\delta_{4}\left(\text { Euro }_{i(t-1)} \times \text { Crisis }_{(t-1)}\right)+\delta_{5} \vec{x}_{i(t-1)}+\delta_{6} \vec{z}_{i}+\delta_{7} t+\mu_{i}+\vec{\rho}_{t}+v_{i t}
\end{aligned}
$$

On the right hand side of Equation (8), $R E E R V O l_{i(t-1)}$ is the first-order autoregressive component, Euro represents a dummy equal to one if the country has adopted the euro and Crisis is a dummy equal to one in Q4:2008. For robustness, we also estimate Equation (8) with two broader crisis definitions including Q4:2008 Q1:2009 and Q4:2008 Q3:2009. As another robustness check, we estimate it separately both in the full OECD sample and in a subsample of European (euro and non-euro) economies. The vector $\vec{x}_{i(t-1)}$ contains lagged time-varying control variables, $\vec{z}_{i}$ contains time-invariant controls, $t$ is a time trend, $\mu_{i}$ is the country-specific random effect, $\vec{\rho}_{t}$ is a set of four quarter dummies to control for seasonality, and $v_{i t}$ is the i.i.d. error term. The set of timevarying controls in $\vec{x}_{i(t-1)}$ includes the current account, the change in reserves, total gross capital flows, inflation and its square, and the volatility of the commodity terms of trade. The time-invariant controls in $\vec{z}_{i}$ include regional and non-emerging OECD country

\footnotetext{
7 Compared to the Hausman-Taylor approach, a potentially more efficient General Methods of Moments (GMM) procedure for dynamic panels relies on Arellano and Bond $(1991,1998)$. However, with 80 quarters per country the length of our time series exceeds the number of countries. This makes the Arellano and Bond procedure infeasible.
} 
dummies. The use of Hausman-Taylor estimators requires that we specify a set of exogenous and a set of endogenous covariates. We assume that all variables, except the volatility of the commodity terms of trade and euro adoption, are endogenous. However, the results are robust in terms of making all variables endogenous.

\section{B. Results}

The estimates in Table 7 imply that euro adoption was associated with about 0.23 standard deviations decline in short-run REER volatility before the Great Recession period. As the coefficient on lagged REER volatility is about 0.4 , the long run volatility change was about 0.4 standard deviations. However, during the Great Recession, the short-run stability gain was larger by an order of magnitude: in the non-euro countries the crisis increased REER volatility by anywhere from $38 \sim 189 \%$ of the OECD sample mean (or 0.4 to 2 standard deviations) depending on the specification. In stark contrast, the crisis had little or no effect on REER volatility in the euro-zone: the sum of the coefficients on Crisis and Crisis*Euro is roughly zero. Since we include country random effects, the positive association between the euro and REER stability does not reflect that euro adopters are inherently more resilient to REER fluctuations. These results lead us to conclude that the euro has stabilized its members' real exchange rates significantly and the effect was particularly large during the Great Recession.

\section{Conclusion}

This paper has studied the effect of Real Effective Exchange Rate (REER) volatility on economic growth as well as the euro's effect on REER volatility. We show that REER volatility is negatively associated with the growth in a panel of OECD countries after correcting for potential endogeneity using a commodity terms of trade instrument. A one standard deviation volatility decrease is associated with a growth increase of approximately two percentage points ( 0.8 standard deviations). We then considered the theoretical underpinnings and some preliminary empirical evidence for the widespread assumption that the euro has stabilized the real exchange rates of member countries. 
Although the euro can in principle destabilize the REER, in practice we find evidence for a strong stabilizing effect. Euro adoption was associated with a decline of 0.4 standard deviations in long-run REER volatility before the Great Recession in 2008 2009. Moreover, while the Great Recession increased REER volatility by $38 \sim 189 \%$ of the sample mean outside the eurozone, the REERs of euro adopters were almost completely insulated. We conclude that REER stability may be growth-enhancing in OECD countries and the euro may therefore have played a growth-enhancing role at least prior to the onset of the eurozone debt crisis in late 2009 or early 2010.

Received 11 May 2013, Revised 8 February 2014, Accepted 20 December 2014

\section{References}

Aghion, P., P. Bacchetta, R. Rancière, and K. Rogoff. "Exchange Rate Volatility and Productivity Growth: The Role of Financial Development." Journal of Monetary Economics 56, 4(2009), 494-513.

Aizenman, Joshua, Sebastian Edwards, and Daniel Riera-Crichton. "Adjustment Patterns to Commodity Terms of Trade Shocks: The Role of Exchange Rate and International Reserves Policies." Journal of International Money and Finance 31, 8(2012), 19902016.

Amemiya, Takeshi and Thomas E MaCurdy. "Instrumental-Variable Estimation of an Error-Components Model”. Econometrica 54, 4(1986), 869-80.

Arellano, M., and Bond, S. R. "Some Tests of Specification for Panel Data: Monte Carlo Evidence and an Application to Employment Equations." Review of Economic Studies, 58, 2(1991), 277-297.

Arellano, M., and Bond, S. R. "Initial Conditions and Moment Restrictions in Dynamic Panel Data Models.” Journal of Econometrics 87, 1(1998), 115-43.

Berka, Martin and Michael B. Devereux. "Trends in European real exchange rates." Economic Policy 28, 74(2013), 193-242. 
Berka, Martin, Michael B. Devereux and Charles Engel. "Real Exchange Rate Adjustment In and Out of the Eurozone." American Economic Review Papers and Proceedings 102, 3(2012), 179-85.

Bosworth, Barry, Susan Collins and Yu-chin Chen 1995. "Accounting for Differences in Economic Growth.” Brookings Institution Discussion Papers No. 115.

Bleaney, Michael F and David Greenaway. "The Impact of Terms of Trade and Real Exchange Rate Volatility on Investment and Growth in Sub-Saharan Africa." Journal of Development Economics 65, 2(2001), 491-500.

Calvo, Guillermo A, Leonardo Leiderman and Carmen M Reinhart. "Inflows of Capital to Developing Countries in the 1990s." Journal of Economic Perspectives 10, 2(1996), 123-39.

Cottani, J.A., Cavallo, D.F., Khan, M.S. "Real Exchange Rate Behavior and Economic Performance in LDCs." Economic Development and Cultural Change 39, 1(1990), 6176.

De Gregorio, J., A. Giovannini, and H. C. Wolf. "International Evidence on Tradables and Nontradables Inflation." European Economic Review 38, 6(1994), 1225-44.

Dixit, A., Pindyck, R.S. Investment Under Uncertainty. Princeton University Press, Princeton, New Jersey, 1994.

Dollar, D. "Outward-oriented Developing Economies Really Do Grow more Rapidly: Evidence from 95 LDCs, 1976-85." Economic Development and Cultural Change 40 (1992), 523-544.

Dornbusch, R. "Purchasing Power Parity." The New Palgrave Dictionary of Economics (Reprint ed.), London: Palgrave Macmillan, 1988.

Eichengreen, Barry. "The Real Exchange Rate and Economic Growth." Social and Economic Studies 56, 4(2007), 7-20.

Ghura, D., Grennes, T.J. "The Real Exchange rate and Macroeconomic Performance in Sub-Saharan Africa.” Journal of Development Economics 42, 1(1993), 155-174.

Greene, William H. Econometric Analysis. New Jersey: Prentice-Hall, 2002.

Hausman, J. and W. Taylor. "Panel Data and Unobservable Individual Effects." Econometrica 49. 6(1981), 1377-1398. 
Martin, Philippe, and Carol Ann Rogers. "Long-term growth and short-term economic instability." European Economic Review 44, 2(2000), 359-381.

Nickell, S. "Biases in Dynamic Models with Fixed Effects." Econometrica 49, 6(1981), 1417-26.

Papaioannou, E. and R. Portes. 2008, “Costs and Benefits of Running an International Currency, European Commission, DG-EC/FIN, Special Report on the European Economy," European Economy Economic Papers No. 348.

Rogoff, K. "The Purchasing Power Parity Puzzle." Journal of Economic literature 34, 2(1996), 647-668.

Stock, James H. and Motohiro Yogo 2002. "Testing for Weak Instruments in Linear IV Regression.” NBER Technical Working Paper No. 284. 
Table 1. Summary statistics

A. Annual data

\begin{tabular}{|l|c|c|c|c|c|}
\hline Variable & Observations & Mean & Std. Dev. & Min & Max \\
\hline Economic Growth & 744 & 0.028 & 0.026 & -0.048 & 0.138 \\
\hline REER Volatility & 699 & 2.022 & 1.384 & 0.411 & 10.096 \\
\hline Non-tradable/tradable TFP Growth & 744 & -0.002 & 0.033 & -0.147 & 0.172 \\
\hline Real GDP/capita & 626 & 25,741 & 8,850 & 7,581 & 59,640 \\
\hline Inflation & 744 & 4.405 & 5.868 & -4.5 & 84 \\
\hline Trade Openness & 528 & 0.409 & 0.226 & 0.079 & 1.383 \\
\hline Commodity Terms of Trade Volatility & 713 & 0.006 & 0.006 & 0.001 & 0.072 \\
\hline
\end{tabular}

\section{B. Quarterly data}

\begin{tabular}{|l|c|c|c|c|c|}
\hline Variable & Observations & Mean & Std. Dev. & Min & Max \\
\hline REER Volatility & 3041 & 1.323 & 1.250 & 0.110 & 13.847 \\
\hline REER Volatility European Subsample & 1192 & 1.143 & 1.222 & 0.114 & 13.637 \\
\hline Current Account* & 2636 & -0.004 & 0.052 & -0.75 & 0.221 \\
\hline Change in Reserves* & 2644 & 0.003 & 0.028 & -0.182 & 0.305 \\
\hline Total Gross Capital Flows* & 2636 & 0.505 & 0.842 & 0.006 & 9.465 \\
\hline Inflation & 3520 & 0.063 & 0.074 & -0.16 & 0.954 \\
\hline CTOT Volatility & 3520 & 0.004 & 0.005 & 0.000 & 0.126 \\
\hline CTOT Volatility, European Subsample & 1292 & 0.005 & 0.007 & 0.000 & 0.126 \\
\hline Total Private Gross Capital Flows* & 2636 & 0.445 & 0.791 & 0.005 & 8.613 \\
\hline
\end{tabular}

(Note) * variables are deflated by nominal GDP 
Table 2. Sample countries

\begin{tabular}{|c|c|c|c|}
\hline Euro Zone & Non-Euro Europe & \multicolumn{2}{|c|}{ OECD } \\
\hline Austria & Denmark & Australia & Israel \\
\hline Belgium-Luxembourg & Iceland & Austria & Japan \\
\hline Finland & Norway & Belgium-Luxembourg & Netherlands \\
\hline France & Sweden & Canada & New Zealand \\
\hline Germany & United Kingdom & Denmark & Norway \\
\hline Greece & Non-Euro OECD & Finland & Spain \\
\hline Ireland & Denmark & France & Sweden \\
\hline Italy & Iceland & Germany & Switzerland \\
\hline Netherlands & Norway & Greece & United Kingdom \\
\hline Portugal & Sweden & Iceland & United States \\
\hline Spain & United Kingdom & Ireland & \\
\hline
\end{tabular}


Table 3. IV Estimates for Growth and REER volatility

\begin{tabular}{|c|c|c|c|c|c|}
\hline $\begin{array}{l}\text { Sample } \\
\text { Second Stage }\end{array}$ & $\begin{array}{l}\text { OECD } \\
\text { Growth } \\
\end{array}$ & $\begin{array}{c}\text { OECD } \\
\text { Growth }\end{array}$ & $\begin{array}{l}\text { OECD } \\
\text { Growth }\end{array}$ & $\begin{array}{l}\text { OECD } \\
\text { Growth }\end{array}$ & $\begin{array}{l}\text { OECD } \\
\text { Growth }\end{array}$ \\
\hline 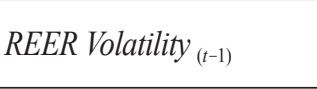 & $\begin{array}{c}-0.017^{* * *} \\
{[0.004]}\end{array}$ & $\begin{array}{c}-0.018 * * * \\
{[0.007]}\end{array}$ & $\begin{array}{c}-0.017 * * * \\
{[0.004]}\end{array}$ & $\begin{array}{c}-0.012 * * * \\
{[0.004]}\end{array}$ & $\begin{array}{c}-0.013 * * * \\
{[0.004]}\end{array}$ \\
\hline Time Trend & $\begin{array}{c}-0.000^{* *} \\
{[0.000]}\end{array}$ & $\begin{array}{c}-0.001^{* * * *} \\
{[0.000]}\end{array}$ & $\begin{array}{c}-0.001^{* *} \\
{[0.000]}\end{array}$ & $\begin{array}{c}-0.001 * * * \\
{[0.000]}\end{array}$ & $\begin{array}{c}-0.001^{* * *} \\
{[0.000]}\end{array}$ \\
\hline Crisis 2008 2009 & $\begin{array}{c}-0.020^{* * *} \\
{[0.003]}\end{array}$ & $\begin{array}{c}-0.018^{* * *} \\
{[0.004]}\end{array}$ & $\begin{array}{c}-0.014^{* * *} \\
{[0.004]}\end{array}$ & $\begin{array}{c}-0.014^{* * *} \\
{[0.003]}\end{array}$ & $\begin{array}{c}-0.016 * * * \\
{[0.003]}\end{array}$ \\
\hline Rel TFP Growth $_{(t-1)}$ & & $\begin{array}{c}-0.001^{* * *} \\
{[0.000]}\end{array}$ & & & \\
\hline In Real GDP $(t-1)$ & & & $\begin{array}{c}-0.532 * * \\
{[0.260]}\end{array}$ & & \\
\hline $\ln$ Real $G D P^{2}{ }_{(t-1)}$ & & & $\begin{array}{l}0.026^{* *} \\
{[0.013]}\end{array}$ & & \\
\hline Inflation $_{(t-1)}$ & & & & $\begin{array}{c}-0.003 * * * \\
{[0.001]}\end{array}$ & \\
\hline Inflation $_{(t-1)}^{2}$ & & & & $\begin{array}{c}0.000 \\
{[0.000]}\end{array}$ & \\
\hline Trade Openness ${ }_{(t-1)}$ & & & & & $\begin{array}{c}0.045 \\
{[0.030]}\end{array}$ \\
\hline $\begin{array}{l}\text { Under-ID test: } \\
\text { Kleibergen-Paap Rk LM } \\
\text { Chi-sq P-val }\end{array}$ & $\begin{array}{l}17.27 \\
0.000\end{array}$ & $\begin{array}{l}11.42 \\
0.000\end{array}$ & $\begin{array}{l}19.78 \\
0.000\end{array}$ & $\begin{array}{l}17.15 \\
0.000\end{array}$ & $\begin{array}{l}20.22 \\
0.000\end{array}$ \\
\hline $\begin{array}{l}\text { Weak ID test: } \\
\text { Kleibergen-Paap Rk } \\
\text { Wald F statistic }\end{array}$ & 39.06 & 15.94 & 24.56 & 40.99 & 29.60 \\
\hline $\begin{array}{l}\text { Stock-Yogo weak } \\
\text { ID test critical values }\end{array}$ & & $\begin{array}{l}\text { Maximal } \\
\text { IV Size }\end{array}$ & $\begin{array}{l}10 \% \\
15 \% \\
20 \% \\
25 \% \\
\end{array}$ & $\begin{array}{l}16.38 \\
8.96 \\
6.66 \\
5.53 \\
\end{array}$ & \\
\hline First Stage Regression & $\begin{array}{c}\text { REER } \\
\text { Volatility }\end{array}$ & $\begin{array}{c}\text { REER } \\
\text { Volatility }\end{array}$ & $\begin{array}{c}\text { REER } \\
\text { Volatility }\end{array}$ & $\begin{array}{c}\text { REER } \\
\text { Volatility }\end{array}$ & $\begin{array}{c}\text { REER } \\
\text { Volatility }\end{array}$ \\
\hline Commodity ToT Vol*(t) $_{\left({ }^{\prime}\right.}$ & $\begin{array}{c}45.49 * * * \\
{[11.189]}\end{array}$ & $\begin{array}{l}66.64 * * * \\
{[17.731]}\end{array}$ & $\begin{array}{l}51.94 * * * \\
{[17.229]}\end{array}$ & $\begin{array}{l}46.66^{* *} \\
{[17.893]}\end{array}$ & $\begin{array}{r}42.51^{* * *} \\
{[10.208]}\end{array}$ \\
\hline Observations & 682 & 251 & 462 & 682 & 462 \\
\hline Number of countries & 22 & 17 & 22 & 22 & 22 \\
\hline
\end{tabular}

(Notes) Robust standard errors in brackets. * denote statistical significant at 10\%; ** denote statistical significant at 5\%; *** denote statistical significant at 1\%. Constant included in all regressions. Annual Data 1980 2011.

The controls are included in the first stage regressions, but the results are not reported. 


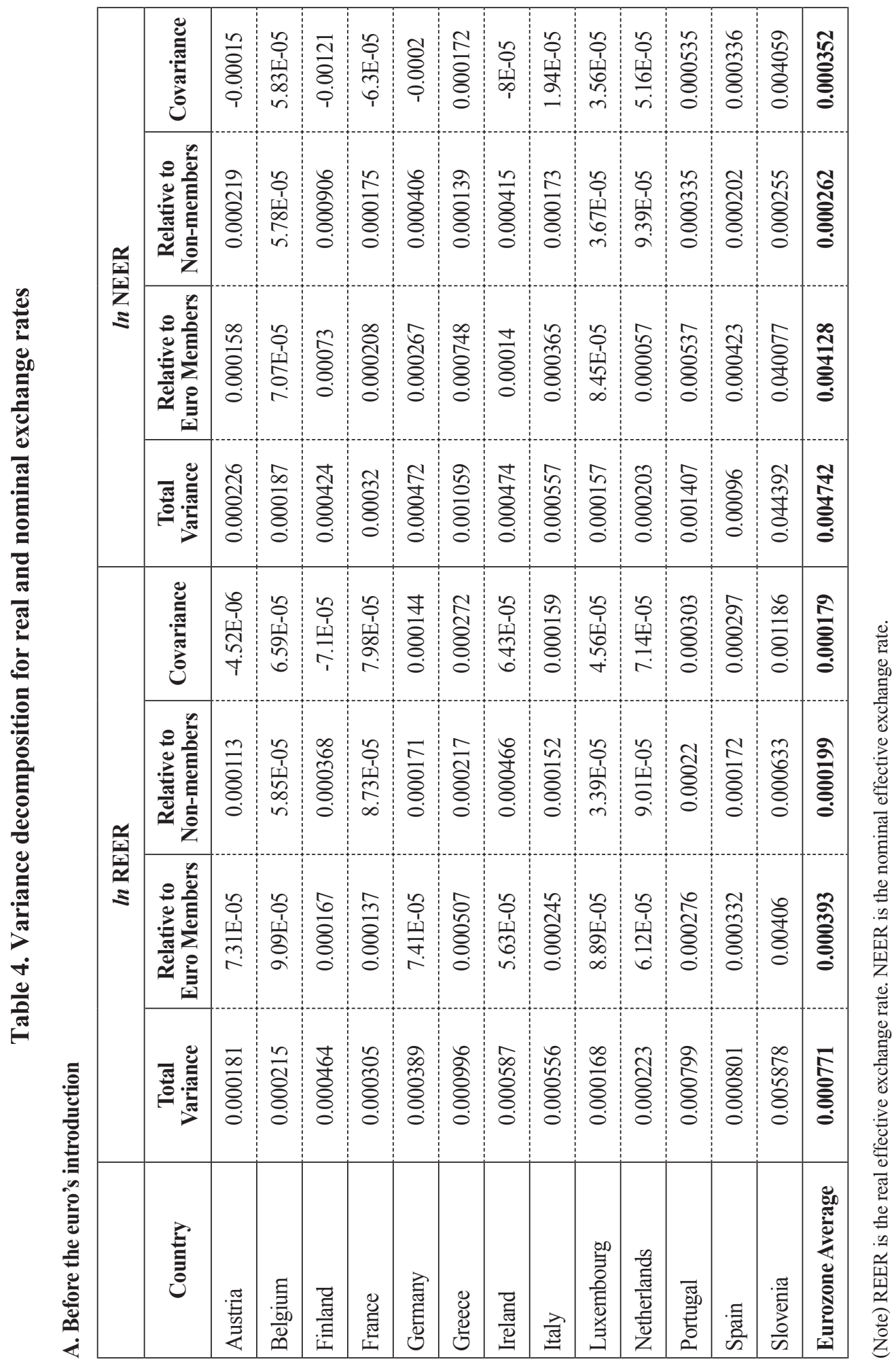




\begin{tabular}{|c|c|c|c|c|c|c|c|c|c|c|c|c|c|c|c|}
\hline \multirow{4}{*}{$\begin{array}{c}\mathbf{c} \\
\mathbf{z} \\
\mathbf{Z} \\
\Xi\end{array}$} & 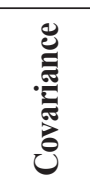 & 0 & 0 & 0 & 0 & 0 & 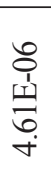 & 0 & $\begin{array}{l}\hat{0} \\
1 \\
n \\
i n \\
i\end{array}$ & 0 & 0 & 0 & 0 & 0 & 훙 \\
\hline & 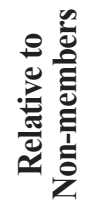 & $\begin{array}{l}n \\
o \\
\text { ț } \\
\stackrel{0}{0} \\
\end{array}$ & 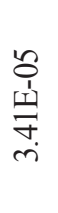 & 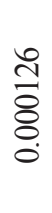 & $\begin{array}{l}n \\
0 \\
1 \\
\sigma \\
\sigma \\
0\end{array}$ & $\begin{array}{l}n \\
0 \\
1 \\
\infty \\
o \\
\infty\end{array}$ & \begin{tabular}{l}
$\stackrel{n}{0}$ \\
章 \\
\multirow{6}{0}{}
\end{tabular} & 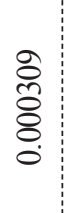 & $\begin{array}{l}n \\
0 \\
1 \\
\\
\infty\end{array}$ & 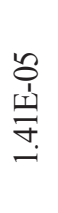 & $\begin{array}{l}\stackrel{2}{0} \\
\stackrel{1}{n} \\
\stackrel{n}{m} \\
\dot{m}\end{array}$ & $\begin{array}{l}n \\
0 \\
1 \\
n \\
\\
\end{array}$ & $\begin{array}{l}n \\
o \\
1 \\
\infty \\
\infty \\
\infty \\
\infty\end{array}$ & 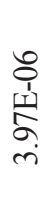 & 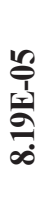 \\
\hline & 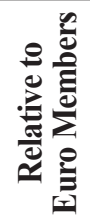 & 0 & 0 & 0 & 0 & 0 & 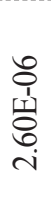 & 0 & $\begin{array}{l}8 \\
1 \\
1 \\
\sigma \alpha \\
\sigma \\
\sigma\end{array}$ & 0 & 0 & 0 & 0 & 0 & 훙 \\
\hline & 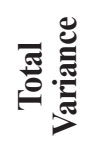 & $\begin{array}{l}n \\
o \\
1 \\
\text { ț } \\
n \\
n\end{array}$ & $\begin{array}{l}\stackrel{n}{0} \\
\stackrel{1}{c} \\
\stackrel{7}{7} \\
\stackrel{n}{r}\end{array}$ & 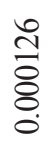 & $\begin{array}{l}n \\
0 \\
1 \\
\sigma \\
\sigma \\
0\end{array}$ & $\begin{array}{l}n \\
o \\
1 \\
\infty \\
o \\
\infty\end{array}$ & 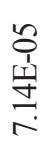 & 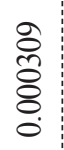 & $\begin{array}{l}n \\
0 \\
1 \\
0 \\
1 \\
\infty\end{array}$ & 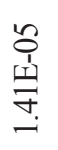 & $\begin{array}{l}\stackrel{2}{0} \\
\stackrel{1}{n} \\
\stackrel{n}{m}\end{array}$ & 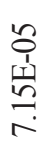 & $\begin{array}{l}n \\
o \\
1 \\
\infty \\
\infty \\
\infty \\
\infty\end{array}$ & 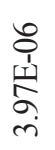 & 承 \\
\hline \multirow{5}{*}{ 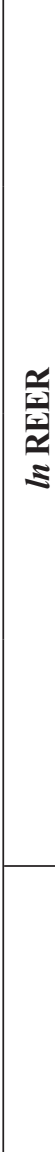 } & 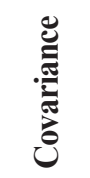 & $\begin{array}{l}8 \\
\varnothing \\
1 \\
\infty \\
\infty \\
\text { i }\end{array}$ & 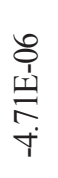 & 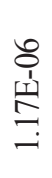 & 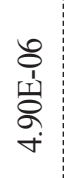 & 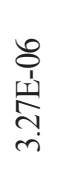 & 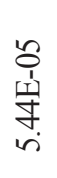 & 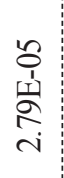 & $\begin{array}{l}\infty \\
0 \\
1 \\
\infty \\
\infty \\
\infty\end{array}$ & $\begin{array}{l}\text { o } \\
\text { Tे } \\
\text { న్ } \\
\text { in }\end{array}$ & 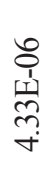 & 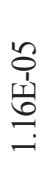 & 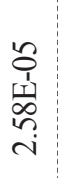 & 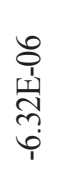 & ب0. \\
\hline & 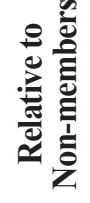 & 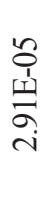 & $\begin{array}{l}\stackrel{n}{0} \\
\stackrel{1}{c} \\
\stackrel{n}{n} \\
\end{array}$ & $\begin{array}{l}\stackrel{\infty}{1} \\
\stackrel{1}{8} \\
\stackrel{8}{0} \\
\dot{0}\end{array}$ & $\begin{array}{l}n \\
0 \\
1 \\
\text { t) } \\
8 \\
r\end{array}$ & 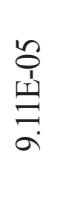 & 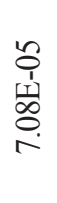 & $\begin{array}{l}+ \\
\delta \\
\delta \\
\delta \\
0\end{array}$ & $\begin{array}{l}n \\
o \\
\frac{1}{m} \\
m \\
\infty \\
\infty\end{array}$ & 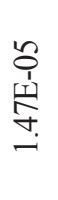 & $\begin{array}{l}\stackrel{2}{o} \\
\text { ț } \\
\stackrel{1}{\circ} \\
\dot{r}\end{array}$ & $\begin{array}{l}n \\
0 \\
1 \\
\\
\infty \\
\end{array}$ & 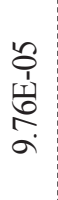 & 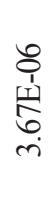 & 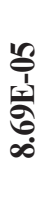 \\
\hline & 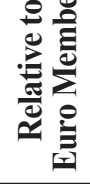 & 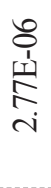 & 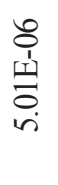 & 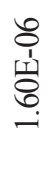 & $\begin{array}{l}0 \\
0 \\
11 \\
n \\
n \\
-1\end{array}$ & 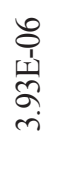 & 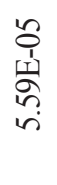 & 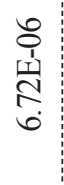 & 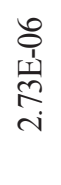 & 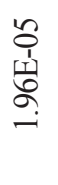 & 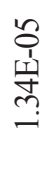 & 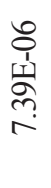 & 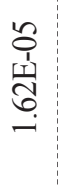 & 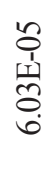 & ڤ̊ \\
\hline & है & 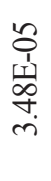 & $\begin{array}{l}\text { ஸे } \\
\delta \\
\delta \\
0\end{array}$ & $\begin{array}{l}\overrightarrow{2} \\
\stackrel{8}{8} \\
\stackrel{8}{0}\end{array}$ & $\begin{array}{l}n \\
0 \\
1 \\
\\
\stackrel{r}{r}\end{array}$ & 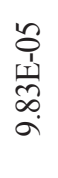 & $\begin{array}{l}\infty \\
\stackrel{\infty}{8} \\
8 \\
0\end{array}$ & 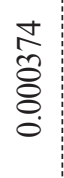 & $\begin{array}{l}n \\
0 \\
1 \\
0 \\
0 \\
\infty\end{array}$ & $\begin{array}{l}\stackrel{2}{0} \\
\stackrel{1}{1} \\
\stackrel{1}{1} \\
\stackrel{+}{+}\end{array}$ & $\begin{array}{l}n \\
0 \\
1 \\
n \\
n \\
n \\
n\end{array}$ & $\begin{array}{l}\stackrel{2}{0} \\
\stackrel{1}{+} \\
\frac{1}{\pi} \\
a\end{array}$ & $\begin{array}{l}\frac{\pi}{8} \\
\frac{8}{8} \\
0\end{array}$ & 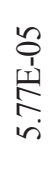 & : \\
\hline & 己̇ & 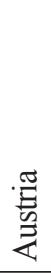 & 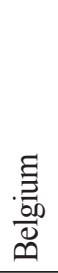 & 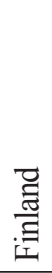 & $\begin{array}{l}\mathscr{U} \\
\text { 预 }\end{array}$ & 胥 & 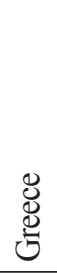 & $\begin{array}{l}\vec{E} \\
\stackrel{\vec{E}}{\mathbb{E}}\end{array}$ & 公 & 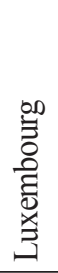 & $\begin{array}{l}\frac{a}{0} \\
\frac{\overrightarrow{0}}{\overline{0}} \\
\frac{\overrightarrow{0}}{Z} \\
Z\end{array}$ & 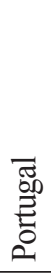 & $\begin{array}{l}\text { : } \\
\text { है } \\
\text { के }\end{array}$ & 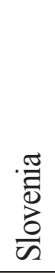 & 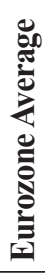 \\
\hline
\end{tabular}


Table 5. Summary of trade weights in the REER variance decompositions

\begin{tabular}{|c|c|c|}
\hline REER of: & Euro share & Non-euro share \\
\hline Austria & 0.65422 & 0.34578 \\
\hline Belgium & 0.80024 & 0.19976 \\
\hline Finland & 0.35079 & 0.64921 \\
\hline France & 0.65568 & 0.34432 \\
\hline Germany & 0.54128 & 0.45872 \\
\hline Greece & 0.70119 & 0.29881 \\
\hline Ireland & 0.31881 & 0.68119 \\
\hline Italy & 0.64822 & 0.35178 \\
\hline Luxembourg & 0.84247 & 0.15753 \\
\hline Netherlands & 0.70740 & 0.29260 \\
\hline Portugal & 0.59704 & 0.40296 \\
\hline Spain & 0.65529 & 0.34471 \\
\hline Slovenia & 0.93888 & 0.06112 \\
\hline Euro zone average & 0.64704 & 0.35296 \\
\hline
\end{tabular}

(Note) Non-euro countries used in the variance decomposition: Brazil, Canada, Chile, Czech Republic, China, Denmark, Estonia, Hungary, India, Indonesia, Israel, Japan, South Korea, Mexico, Norway, Poland, Russian Federation, Slovak Republic, South Africa, Sweden, Switzerland, Turkey, United Kingdom, United States. 


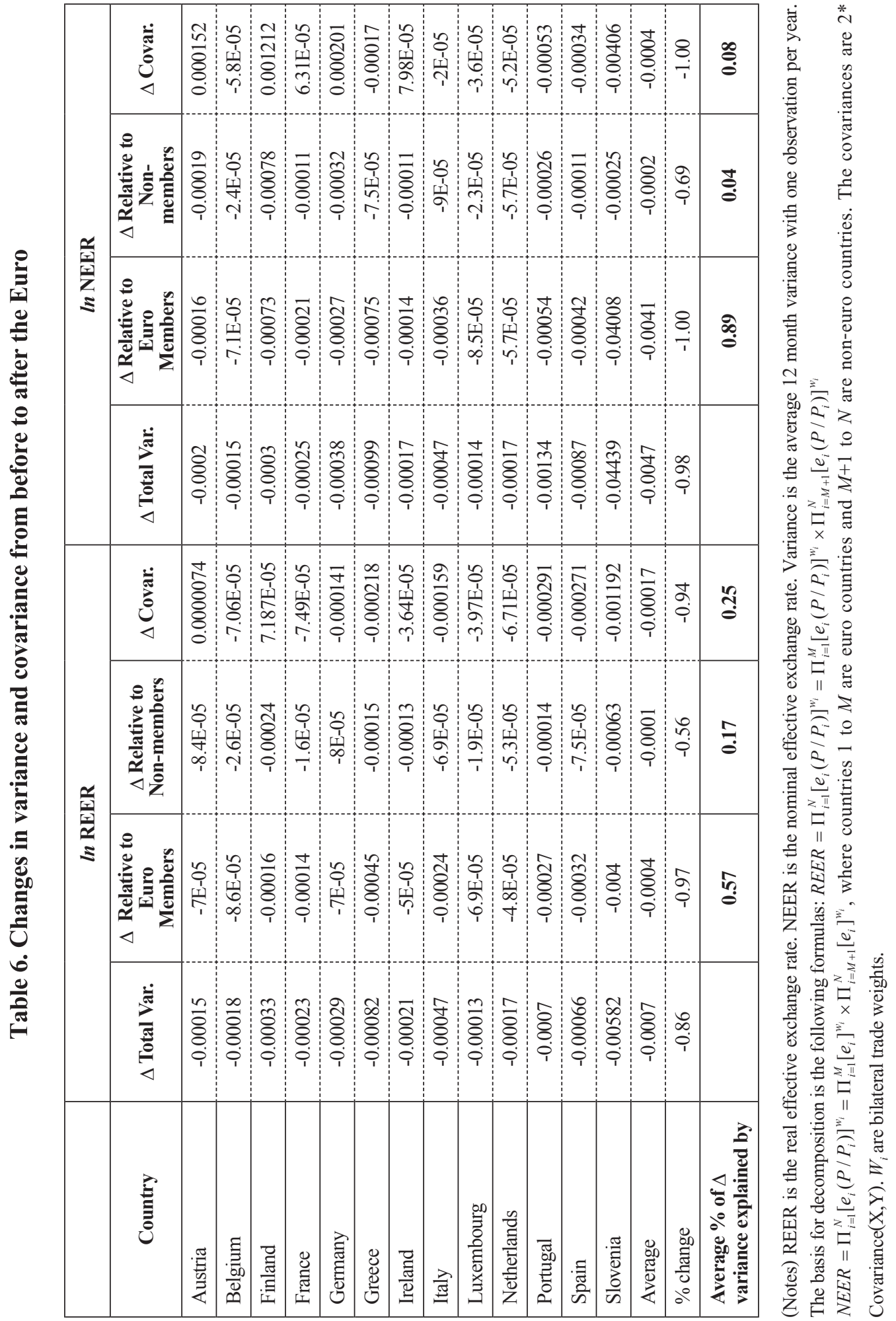




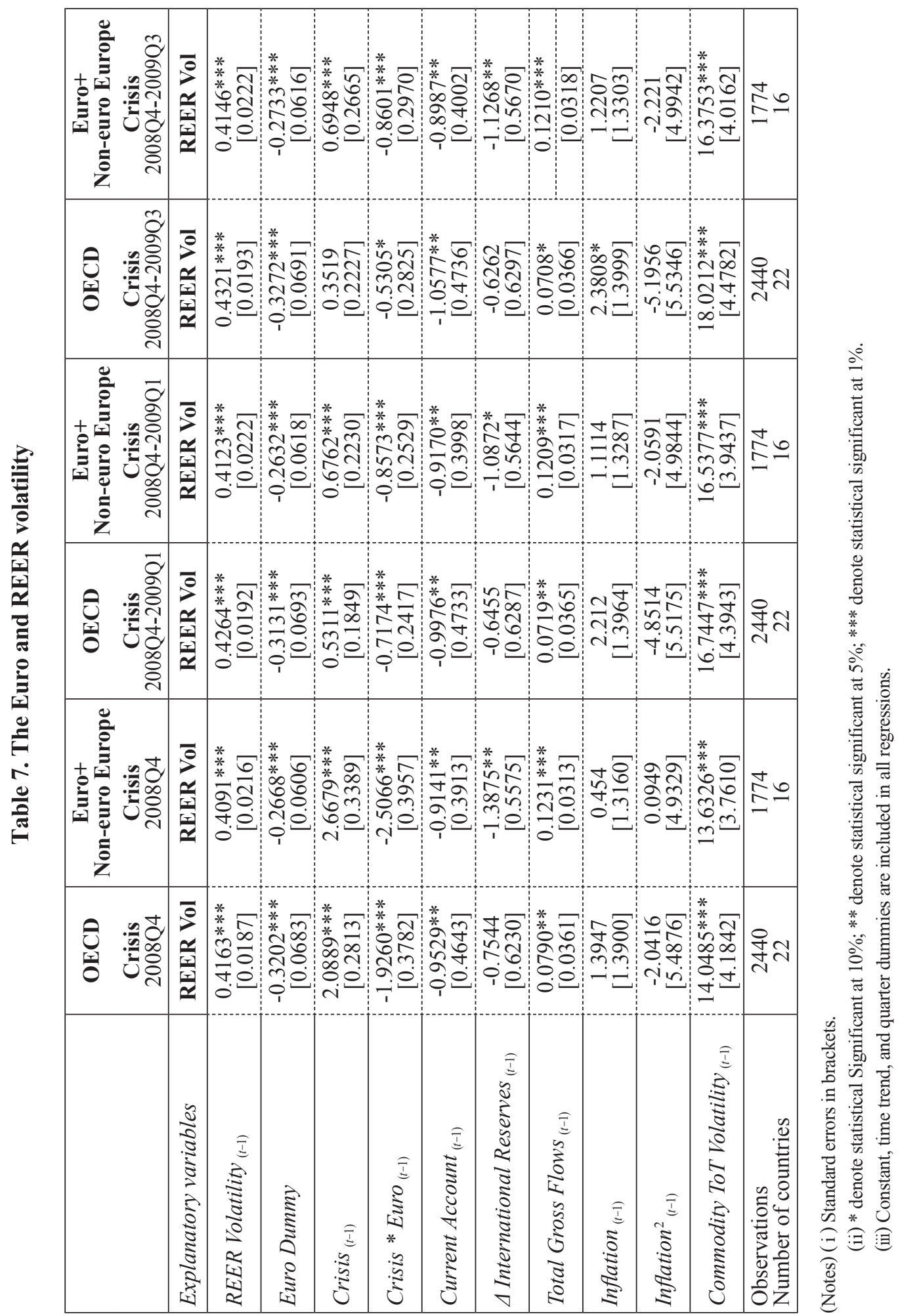




\section{Figure 1. REER volatility}

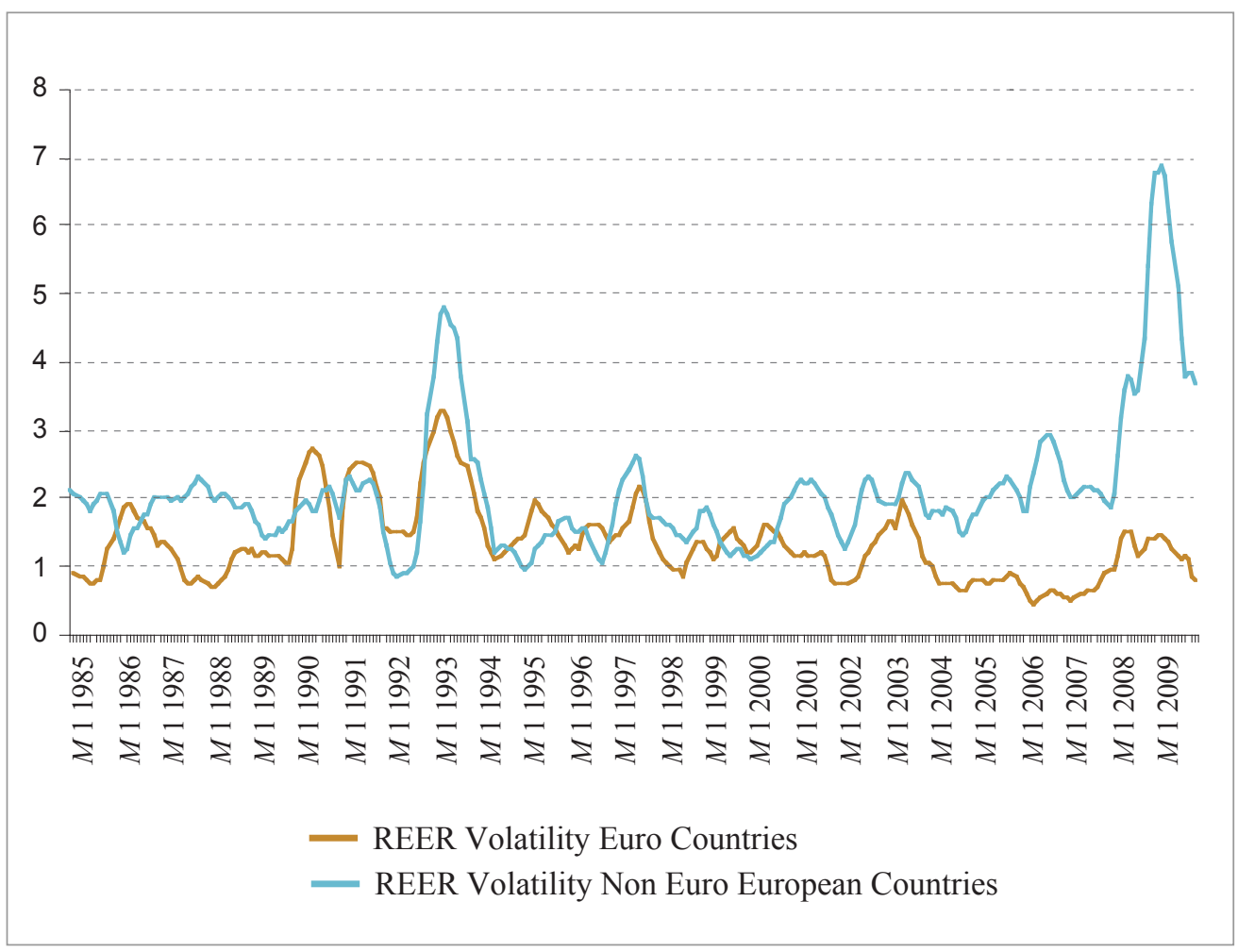

(Note) The two curves show average REER volatility for euro- and non-euro adopters before as well as after euro adoption in 1999. 
Figure 2. Real effective exchange rates

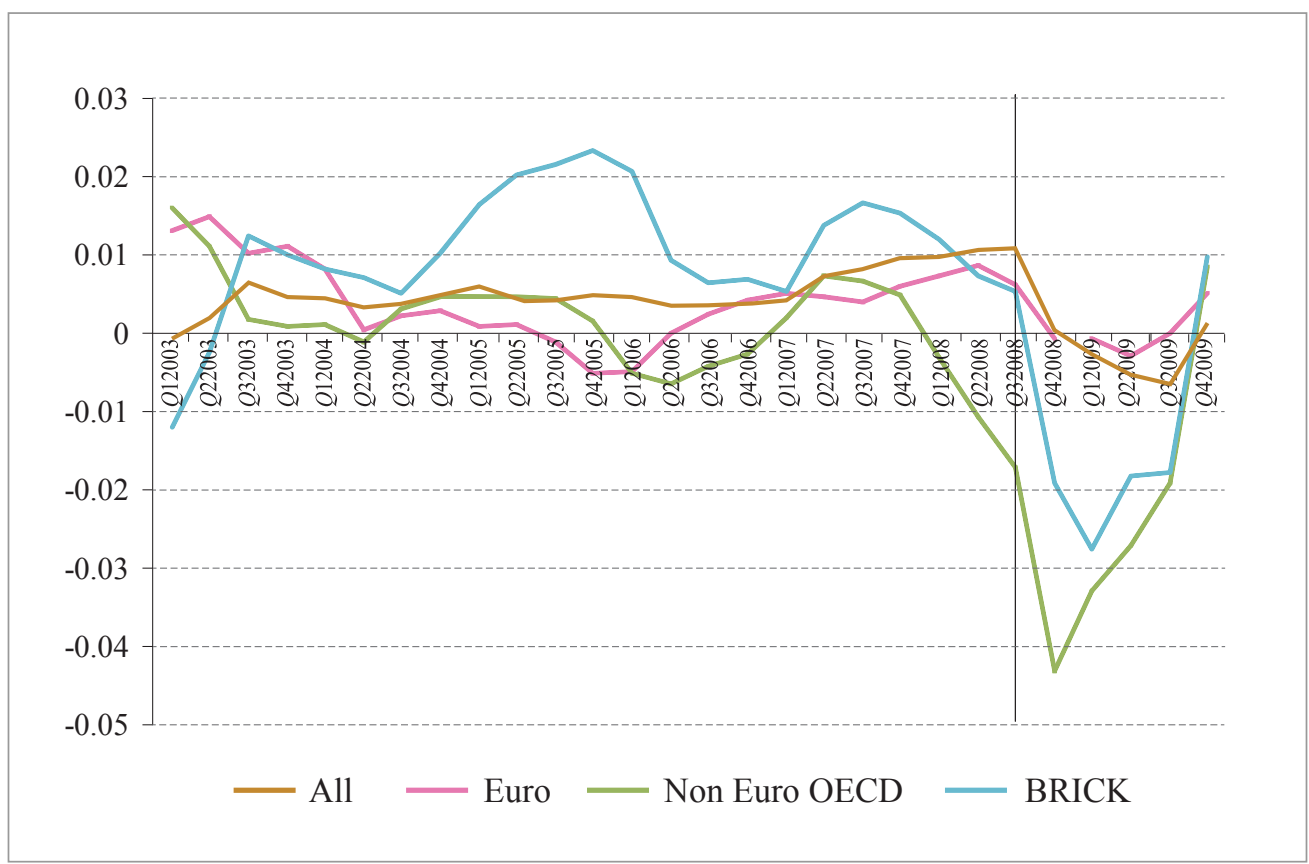

(Note) We include the emerging markets of Brazil, Russia, India, China and South Korea (BRICK) for comparison. 